Open Access

\title{
Innovation capability and its role in enhancing the relationship between TQM practices and innovation performance
}

Maha Mohammed Yusr

Correspondence:

maha_yusr@yahoo.com

University Utara Malaysia, Sintok, Kedah, Malaysia

\begin{abstract}
Innovation plays a critical role in predicting the long-term survival of organizations, determining an organization's success and sustaining its global competitiveness, especially in an environment where technologies, competitive position and customer demands can change almost overnight, and where the life-cycle of products and services are becoming shorter. Therefore, the main purpose of this paper is to extend the existing knowledge as to the relationship between TQM practices and innovation performance by exploring the expected role of innovation capability as mediator to enhance this relationship. At the same time, this study attempted to shed a light on how to improve innovation performance of manufacturing companies in Malaysia. The gained results indicated that innovation capability mediates the relationship between TQM practices and innovation performance. More importantly, this study supports the findings of the past studies that questioned the role of TQM practices in improving innovation performance. Finally, in light of the obtained results, several recommendations were introduced to assist decision makers in manufacturing companies.
\end{abstract}

Keywords: Innovation performance, Innovation capability, TQM practices, RBV theory, Partial Least Square PLS

\section{Introduction}

Like all business sectors, the manufacturing sector is affected to the extent of threatening the survival of firms by high level of competition in the market, either locally or globally. The manufacturing firms react by aiming for and maintaining market share, customer loyalty, customer satisfaction, competitive advantage, etc. In Malaysian context, the abilities of Malaysian manufacturers to compete is still under par compared to the countries in the South Asian region (10th Malaysia Plan 2010). According to the Economic Planning Unit EPU under the Prime Minister Department Malaysia, to achieve competitive advantage or improve the competitive abilities, the Malaysian manufacturing sector needs, among others, to enhance its innovation performance (10th Malaysia Plan 2010). Although the Malaysian manufacturing sector plays an important role in Malaysia's economic growth and contributes approximately $25.1 \%$ of Malaysian Gross Domestic Product (GDP), the performance of this sector has been witnessing a decline since 2010 (10th Malaysia Plan 2010; Ministry of

(c) 2016 Yusr. Open Access This article is distributed under the terms of the Creative Commons Attribution 4.0 International License (http://creativecommons.org/licenses/by/4.0/), which permits unrestricted use, distribution, and reproduction in any medium, provided you give appropriate credit to the original author(s) and the source, provide a link to the Creative Commons license, and indicate if changes were made. 
Finance 2012). Since manufactured goods comprise about $76.6 \%$ of total exports, the export sector was affected negatively, which in turn, affected the Malaysian GDP (Ministry of Finance 2011).

According to Tuah et al. (2009), focusing on improving innovation performance is the best way to enhance the performance and competitive abilities of the Malaysian manufacturing sector. Tuah et al. (2009) added that focusing on improving innovation performance is the best way to enhance the performance and competitive abilities of the Malaysian manufacturing sector. However, the result of the National Survey of Innovation, 2005-2008 (2011) pointed out that innovation performance of the manufacturing sector is low and needs to be reinforced. Moreover, in 2010, More specifically, the World Bank reported that the innovativeness of Malaysian manufacturing companies retreated in the period between 2002 and 2007, which clearly indicates that more efforts and studies have to be carried out to improve the innovation performance of the manufacturing sector in Malaysia.

In this respect, its well-known that innovation plays a critical role in predicting the long-term survival of organizations, determining an organization's success and sustaining its global competitiveness, especially in an environment where technologies, competitive position and customer demands can change almost overnight and the lifecycle of products and services are becoming shorter (Cobbenhagen 2000; Cooper 1998; Herbig 1995; Pavlou and El Sawy 2011; Porter 1980). Empirically, TQM, as a strategy, has proven its effectiveness in improving the organizational performance in different aspects (customer satisfaction, financial, productivity, etc.) (Martínez-Costa and JiménezJiménez 2008; Prajogo and Hong 2008; Prajogo and Sohal 2006; Sadikoglu and Zehir 2010). However, the studies that investigated the relationship between TQM practices and innovation performance could not provide a clear picture about this relationship (López-Mielgo et al. 2009; Pekovic and Galia 2009; Prajogo and Sohal 2003; Singh and Smith 2004). Accordingly, there is need to conduct more studies in order to clarify the impact of TQM on innovation performance.

On the other hand, Lau et al. (2010) affirmed that building the capabilities of the organization in various areas is an essential step to reinforce the innovation performance of the organizations. In this respect, several scholars have admitted that innovation capability of an organization is considered as one of the key antecedents that influence the innovation performance of the organization (Han et al. 1998; Teece et al. 1997; Yam et al. 2004, 2011). Therefore, examining the impact of TQM practices on innovation performance through mediating role of innovation capability could enhance the existing literature as far as the relationship between TQM practices and innovation performance is concerned.

By carrying out this research several objectives are expected to be achieved to narrow the existing gaps in the literature. First, the information available on each TQM practice and innovation performance makes it evident that the studies dedicated to these concepts are repetitive and abundant; however, the issue of their relationship has been less frequently examined and only a few studies, in the strict sense, have dealt with this (Perdomo-Ortiz et al. 2006). Moreover, the findings of these studies are still inconclusive (Abrunhosa and Sá 2008; Pekovic and Galia 2009). While some studies support the positive impact of TQM practices on innovation performance (López-Mielgo et al. 2009; Pekovic and Galia 2009; Prajogo et al. 2004), 
other researchers questioned the role of TQM practices in enhancing innovation performance (Abrunhosa and Sá 2008; Prajogo and Sohal 2006; Singh and Smith 2004). Thus, it has been recommended that this relationship be re-examined to get more insight regarding this issue (Prajogo and Sohal 2004; Pekovic and Galia 2009; Singh and Smith 2004).

Second, majority of the previous studies examined the direct relationship between TQM practices and innovation performance (e.g. López-Mielgo et al. 2009; Singh and Smith 2004; Prajogo and Sohal 2003; Pekovic and Galia 2009) while the indirect relationship between TQM practices and innovation performance has somewhat been ignored - in regards to this, it could well be that the TQM constructs and innovation are related in a more complex way rather than a simplistic (direct) relationship, which somehow justifies the inconclusive findings among the past studies (Singh and Smith 2004). Therefore, by adopting the approaches that support the positive relationship between TQM and innovation performance, Prajogo and Sohal (2003) recommended investigating this relationship (i.e., TQM practices and innovation performance) through other mediating practices or techniques to determine innovation performance. Since the concept of innovation is captured by innovation capability, as an antecedent of innovation performance, it is necessary to investigate the relationship between TQM and innovation performance through innovation capability (Perdomo-Ortiz et al. 2006).

Third, to the best of our knowledge, most of the past studies did not rely on a certain theory to explain the relationship between TQM practice and innovation performance, hence, this study uses the Resource Based Theory (RBV) as a base to introduce the framework proposed in the study. The next section study deals with the literature that discusses the relationships among the proposed variables upon which the constructed theoretical framework with hypotheses are introduced. This is followed by the discussion about methodology, instrument, data collection and data analysis. Finally, the findings, discussion, limitations and future research recommendations are presented.

\section{Theoretical framework and hypotheses}

The arguments on the relationship between TQM and innovation have been classified into two groups: the first group supports the positive relationship between TQM and innovation, whereas the second group claims that TQM does not support innovation in firms (Cole and Matsumiya 2008; Pinho 2008; Singh and Smith 2004). Arguments that support a positive relationship between TQM and innovation argue that firms adopting TQM and applying it in their system and culture provide a prolific environment to become innovative (Kanji 1996; Roffe 1999; Tang 1998). They claim that the reason behind this opinion is that the principles of TQM provide the platform for innovation (Roffe 1999; Tang 1998; Kanji 1996).

One of these principles is customer focus, which makes the firms constantly looking for customers' needs and their expectations, which leads the firms to be innovative. Also, customer focus is about delighting customers and this requires the firm to do what is creative to exceed those needs and expectations (Prajogo and Sohal 2001). Likewise, continuous improvement encourages firms to adopt changes and creative thinking regarding how the work should be organized and 
executed; in the same context, the principles of empowerment and involvement of teamwork are essential to successful organizational innovation (Prajogo and Sohal 2001). Also, there are several empirical studies that support this direction. For example, Prajogo and Sohal (2004) examined the effect of TQM on innovation, and posited that TQM includes two different models of practices, i.e., mechanistic and organic, which have different effects on the various kinds of innovation. Their finding suggested pairing the organic elements with innovation performance to enhance the latter.

In a related study, Perdomo-Ortiz et al. (2006) investigated the link between the broader concepts of TQM and innovation. They introduced an empirical study of 102 firms, and concluded that there is a positive relationship between TQM and innovation performance. Meanwhile, Prajogo and Hong (2008) presented an empirical study regarding the role of TQM practices on $R \& D$. The data was gathered from $130 \mathrm{R} \& \mathrm{D}$ divisions of Korean manufacturing organizations. They concluded that TQM has a strong effect on product innovation. Also, Pekovic and Galia (2009) found that quality practice positively enhances innovation performance, where the former, whether in human or technological dimensions, helps to create an environment and culture that support innovation. Furthermore, many practices, such as customer orientation, employees' involvement, improved leadership and team spirit under the quality umbrella, enhance innovation performance.

On the other hand, the views that reject the positive relationship between TQM and innovation were raised by many scholars, like Singh and Smith (2004), Prajogo and Sohal(2006), Abrunhosa and Sá (2008), Cole and Matsumiya (2008) among others. This group argued that quality improvement activities may be properly managed to achieve incremental innovation, which is not suitable for industries in which technological and market changes are rapid and radical (Cole and Matsumiya 2008). Moreover, TQM principles that build an organizational culture have made it difficult for the organization to adopt and respond to different market requirements (Cole and Matsumiya 2008), such as customer focus philosophy. This makes firms concentrate only on incremental improvement in their current products and activities, instead of trying to innovate on new solutions, which then leads to introducing uncompetitive products (Prajogo and Sohal 2001).

This group also highlighted that certain aspects of TQM, like continuous improvement, can negatively affect the spirit and initiative of the workers since they are merely involved in repetitive cycles of improvement, without any enhanced learning processes (Prajogo and Sohal 2001). In other words, the focus on incremental improvement leads to unambitious aims. Furthermore, incremental improvement inhibits breakthrough performance, which prevents firms from achieving a more timely progress compared to their competitors (Prajogo and Sohal 2001). In other words, the culture that emphasizes only on catch-up strategy will soon become obsolete.

One of the principles that may harm the abilities of an organization to be more innovative is customer satisfaction. This is because customer satisfaction strategy focuses on existing customers, which is inconsistent with innovation basics that emphasizes on informing and educating customers rather than listening to them to introduce new products (Wind and Mahajan 1997). The emphasis of TQM on cost saving is also one of the obstacles that limit the innovative abilities of organizations (Prajogo and 
Sohal 2001). As mentioned earlier, process improvement failure to enhance innovation can be associated to learning process (Prajogo and Sohal 2001; Perdomo-Ortiz et al. 2006). The main idea in quality management, based on the famous term in the quality literature referred to as "management by fact" to achieve aims of improvement, depends on using analytical, structured and linear thinking while innovation is more synthetic, unstructured and non-linear (Roffe 1999).

The previous review clearly shows conflicting findings regarding the effect of TQM on innovation performance. Table 1 shows the summary of past studies that referred to the relationship between TQM and innovation, where some of the latest studies conducted after 2000 are highlighted.

In spite of conflicting findings in the previous studies as to the relationship between TQM and innovation, this study adopts the stream of the studies that contend that TQM practices have positive influence on innovation performance. Given the afore-mentioned evidences and many empirical findings that have establish the relationship between TQM practices and innovation performance, the following hypothesis is proposed:

\section{H1: TQM practices positively influence innovation performance.}

The RBV theory views the organization as an integration of resources and capabilities (Wernerfelt 1984) and that the organization can achieve superior performance and competitive advantage by developing and deploying unique and distinguished organizational resources and capabilities (Barney 1991; Wernerfelt 1984). In other words, the more distinguished the resources and capabilities are, the more valuable will be the achievement and sustenance of superior performance. Innovation capability basically refers to the firm's ability to continuously transform knowledge and ideas into

Table 1 Summary of the previous studies that examined the relationship between TQM and innovation during 2000-2010

\begin{tabular}{|c|c|c|c|}
\hline No. & Authors & Finding & Positive/negative \\
\hline 1. & Singh and Smith 2004 & $\begin{array}{l}\text { There is no sufficient statistical evidence to } \\
\text { support the relationship between TQM and } \\
\text { innovation performance. }\end{array}$ & No relationship \\
\hline 2. & Prajogo and Sohal 2004 & $\begin{array}{l}\text { Some of the TQM practices have positive } \\
\text { effect on product innovation. }\end{array}$ & Partial positive. \\
\hline 3. & Prajogo and Sohal 2006 & $\begin{array}{l}\text { TQM cannot affect innovation without } \\
\text { integrating with other key resources of } \\
\text { innovation, such as technology and R\&D. }\end{array}$ & $\begin{array}{l}\text { No significant direct } \\
\text { relationship. }\end{array}$ \\
\hline 4. & Perdomo-Ortiz et al. 2006 & $\begin{array}{l}\text { The study stresses strong link between } \\
\text { both TQM and innovation }\end{array}$ & Positive \\
\hline 5. & Cole and Matsumiya 2008 & Quality culture can inhibit innovation. & Negative \\
\hline 6. & Prajogo and Hong 2008 & $\begin{array}{l}\text { TQM principles enhance innovation } \\
\text { performance of organization. }\end{array}$ & Positive \\
\hline 7. & Abrunhosa et al. 2008 & $\begin{array}{l}\text { The relationship between TQM and } \\
\text { innovation is weak and not } \\
\text { statistically significant. }\end{array}$ & Weak relationship \\
\hline 8. & Pekovic and Galia 2009 & $\begin{array}{l}\text { Support the proposition that quality } \\
\text { practices improve innovation. }\end{array}$ & Positive \\
\hline 9. & López-Mielgo et al. 2009 & $\begin{array}{l}\text { Strongly affirms the positive link } \\
\text { between innovation and TQM. }\end{array}$ & Positive \\
\hline 10. & Sadikoglu and Zehir 2010 & $\begin{array}{l}\text { Continuous improvement and process } \\
\text { management can be combined for } \\
\text { breakthrough innovation. }\end{array}$ & Positive \\
\hline
\end{tabular}


new products, processes and systems for the benefit of the organization (Hurley and Hult 1998; Lawson and Samson 2001). Several researchers have asserted that innovation capability can positively enhance organizations' performance in areas such as finance, market share and innovation (Calantone et al. 2002; Lau et al. 2010; Tuominen and Hyvönen 2004).

Furthermore, innovation capability is regarded as an organization's critical capability to deploy resources, with a new capacity to create value (Yang et al. 2009). Moreover, innovation capability is the skill and knowledge needed to effectively absorb, master and improve existing technologies, and to create new ones (Lall 1992). Meanwhile, Cavusgil et al. (2003) described innovation capability as critical antecedents to achieve superior innovation performance, which provides the potential for effective innovation performance.

To sum up, capabilities in general, have been considered as the antecedents for good performance (Zheng et al. 2011). Since innovation is one of the aspects that organizations perform to achieve many organizational aims, it can be argued that innovation capabilities are positively related to innovation performance (Lau et al. 2010). Therefore, the following hypothesis is introduced:

H2: Innovation capabilities positively influence innovation performance.

Although the relationship between TQM and innovation capability have been receiving the attention of both practitioners and researchers circles, the studies that have interpreted this relationship remain scarce. On the other hand, studies focused on the expected role of this relationship in enhancing the performance in general, and innovation in particular take up a major proportion of literature in this topic (Perdomo-Ortiz et al. 2009). TQM practices in organizations are considered to be a forerunner for the accumulation of innovation capability and, consequently, innovating practices and routines are considered as good practices derived from quality management (Perdomo-Ortiz et al. 2006). In 2009, Perdomo-Ortiz et al., evaluated the moderating and mediating role of innovation capability between TQM and technological innovation. In their empirical study, 185 Spanish companies from industrial sectors (machinery and equipment) comprised their sample. The result did not support the moderating role of innovation capability but it supported the mediating role of innovation capability between TQM and technological innovation.

According to Perdomo-Ortiz et al. (2006), TQM creates a favourable and fertile atmosphere or platform for developing innovation. The authors concluded that innovation capabilities can be achieved best through TQM practices, where each practice of TQM affects certain aspects of innovation capabilities. Undoubtedly, the role of leadership commitment is critical to improving the capabilities, whereby under the TQM concept, the top management must be keen to provide necessary requirements and skills that can help to achieve high quality performance throughout the organization (Ahire and O'Shaughnessy 1998). This tendency, in turn, makes top management interested to develop and improve the employees' skills and update the organization with new technologies that support manufacturing, marketing, planning and R\&D capabilities.

Furthermore, other TQM practices like customer focus and supplier quality management help the organization to determine the kinds of capabilities they need to be concerned more with to come out with desired products (Kaynak 2003; Kordupleski et 
al. 1993). People management is also one of the critical practices that the TQM concept emphasizes on, where through this practice, the most important resource, which is human resources, will be activated, developed and undated with new knowledge through different kinds of training programs (Ahire and O'Shaughnessy 1998; Brah et al. 2002). Moreover, managing the processes and reporting the cases of failed performance help to increase the organization's abilities to learn from their mistakes and provide the organization with extensive experiences (Choi and Liker 1995; Lockamy 1998). Consequently, the following hypothesis is formulated:

H3: TQM practices positively influence innovation capabilities.

Applying TQM practices within the organization provides and enhances the organizations skills and capabilities, and this would in turn, reflect positively on the performance. Moreover, discussing the relationship between TQM and innovation capabilities based on the RBV Theory perspective strongly justifies this kind of relationship. As is well known, resources lead to capabilities (Amit and Schoemaker 1993). Therefore, the main idea is, TQM practices in the organizations provide different kinds of resources, whether tangible or intangible and these resources help to build and provide capabilities that can be related to innovation within the organization.

In this regard, implementing a group of practices belonging TQM like leadership management and commitment, customer focus, people management, process management, supplier quality management and quality data reporting supports the organization with several resources, such as skills, knowledge, experience, relationships, tools, communications, systems among others. Having such resources help to build the organization capabilities in certain aspects. More specifically, it will help to improve the R\&D capabilities, marketing capabilities, manufacturing capabilities and planning capabilities. Enhancing such capabilities leads to improve and support the innovation performance. In other words, the effect of TQM on innovation performance might come through the role of TQM in enhancing the innovation capabilities. Thus, the following hypothesis is proposed:

H4: Innovation capability mediates the relationship between TQM practices and innovation performance.

The framework of this paper is founded by thoroughly reviewing the relevant literature. Figure 1 describes the direct and mediated relationships that enhance innovation performance.

\section{Research methodology}

Measure

The measure employed in this paper was drawn from the relevant literature, which confirmed their validity and reliability over time. To measure innovation performance, the instrument was adopted from, Singh and Smith (2004) and Prajogo and Sohal

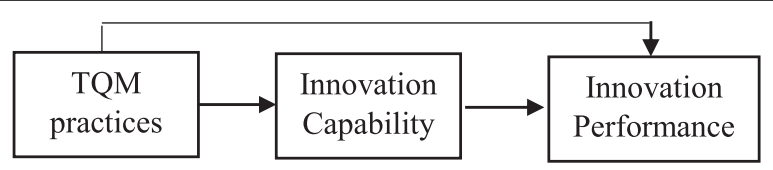

Fig. 1 Research framework 
(2006). The measure of innovation capability was adopted and modified from Yam et al. (2004) study. Finally, TQM practices were measured through items adopted and modified from Black and Porter (1996) and Singh and Smith (2004). All the measures were based on a seven-point Likert-type scale ranging from 1 (strongly disagree) to 7 (strongly agree).

\section{Data collection}

Through the use of mail survey approach, five hundred (500) questionnaires were mailed to the manufacturing companies in Malaysia listed in FMM 2014 directory. The study targeted one manager from each company and determined certain positions to be targeted such as: CEO, R\&D manager, operation manager, manager of quality department. This is because we believe that people who hold these positions have accurate information of their companies with regard to the issue under investigation. A total of 166 questionnaires were returned after which a frequency test was run for each variable to screen and clean the data from any missing responses. Out of 166, 19 questionnaires were found to be incomplete and were therefore rejected. Hence, a total of 147 questionnaires (response rate $21 \%$ ) were considered valid and usable to analyse the data. Such response rate is relatively similar to that reported by Ahmed (2011). Moreover, it should be noted that $21 \%$ rate is acceptable rate for this kind of studies (studies examining the organizational level). Table 2 below describes the demographic data of the respondents. It is evident from the table that majority of the companies were medium and small size, and that majority of the managers (101) were quality and operation managers.

Table 2 Distribution of the respondents by demographic variables $(n=147)$

\begin{tabular}{llll}
\hline Variables & Items & Frequency & Percent \\
\hline Position & CEO & 9 & 6.1 \\
& Manager of quality & 47 & 32.0 \\
& Manager of operation & 54 & 36.7 \\
& Manager of R\&D & 21 & 14.3 \\
& Others & 16 & 10.9 \\
& & 147 & $100 \%$ \\
Total & $151-250$ & 64 & 43.5 \\
Employees & 251-500 & 59 & 40.1 \\
& More than 500 & 24 & 16.3 \\
Total & & 147 & $100 \%$ \\
Ownership & Fully local (0 \% foreign) & 88 & 59.9 \\
& Majority local (48 \% foreign) & 18 & 12.2 \\
& Majority foreign (52 \% foreign) & 9 & 6.1 \\
Fully foreign (100 \% foreign) & 32 & 21.8 \\
Total & & 147 & $100 \%$ \\
Year of Establishment & Less than 5 years & 6 & 4.1 \\
& Between 6 to 10 years & 19 & 12.9 \\
& Between 11 to 15 years & 91 & 61.9 \\
& More than 15 years & 31 & 21.1 \\
& & 147 & $100 \%$ \\
\hline
\end{tabular}




\section{Statistical analysis techniques}

The proposed model was examined using structural equation modelling (SEM) approach - more specifically, SmartPLS version 2.0. M3. The measurement model was evaluated using Confirmatory Factor Analysis (CFA) to confirm the construct validity. After establishing the construct validity, the structural model was examined to test the proposed hypotheses.

\section{Data analysis}

\section{Measurement model}

To guarantee that only reliable and valid constructs' measures were used, before assessing the nature of relationships in the overall model, the validity and reliability of the items and constructs in the measurement model were tested. To do so, the content validity and construct reliability were tested. As for content validity, individual construct reliability is assessed by examining the loadings of respective items on their respective latent construct (Hulland 1999). In order to confirm the content validity, Hair et al. (2011) recommended that the standardized loading estimates should be 0.5 or higher and ideally 0.7 or higher. Table 3 shows that all the items were highly and significantly loading to measure their respective construct.

Construct reliability was established by testing convergent validity. To achieve that, some indicators were used like internal consistency of the items (Cronbach $\alpha$ coefficient), Composite Reliability (CR) and the Average Variance Extracted (AVE). As recommended by many researchers (e.g. Hair et al. 2011; Henseler et al. 2009), the acceptable threshold for internal consistency and composite reliability is 0.70 . Moreover, it has been also suggested that values between 0.60 and 0.70 may be accepted provided that all other conditions of construct validity are satisfied.

Similarly, as for AVE, Henseler et al. (2009) and Hair et al. (2011) stated that an AVE value greater than 0.50 indicates that a latent variable is able to explain more than half of the variance of its indicators on average. However, if the AVE is less than 0.5, this indicates, on average, that the construct explains less variance in the items that remains (in error) unexplained. Table 4 depicts the results of Confirmatory Factor Analysis (CFA) and it shows that all the items comprising the measurement model met the threshold level suggested above.

To test the construct reliability completely, discriminant validity should be examined. Discriminant validity refers to the extent to which a group of items estimate only one construct and how this construct is distinctly estimated (Byrne 2010; Hair et al. 2010). Basically, if a specific construct is more correlated with another construct than with its own measures, there is the possibility that the two constructs share the same types of measures and are not conceptually distinct (Chin 2010). Discriminant validity was tested through the criteria suggested by Fornell and Larcker (1981), where the square root of AVE values of each construct should be higher than the correlations among the constructs. As Table 5 indicates that the square root of AVE values of each constructs in this study were higher than the correlation values of the constructs. Having such result confidently confirms that the model has adequate reliability and validity.

\section{Structural model}

Having established measurement model, the following step is to test the formulated hypotheses. To do that, structural model was tested by running PLS-SEM algorithm 
Table $3 T$-value of the factor loadings

\begin{tabular}{|c|c|c|c|c|c|}
\hline Constructs & Items & Loading & Standard Error & T-Value & $P$-Value \\
\hline \multirow[t]{8}{*}{$\mathrm{IP}$} & IP1 & 0.822 & 0.028 & 29.823 & 0.000 \\
\hline & IP2 & 0.867 & 0.026 & 32.955 & 0.000 \\
\hline & IP3 & 0.813 & 0.036 & 22.686 & 0.000 \\
\hline & IP4 & 0.832 & 0.029 & 28.518 & 0.000 \\
\hline & IP5 & 0.796 & 0.039 & 20.236 & 0.000 \\
\hline & IP6 & 0.828 & 0.040 & 20.617 & 0.000 \\
\hline & IP7 & 0.702 & 0.068 & 10.309 & 0.000 \\
\hline & IP8 & 0.818 & 0.036 & 22.899 & 0.000 \\
\hline \multirow[t]{7}{*}{ IC } & $\mathrm{IC} 1$ & 0.763 & 0.045 & 16.968 & 0.000 \\
\hline & IC2 & 0.782 & 0.040 & 19.698 & 0.000 \\
\hline & IC3 & 0.855 & 0.027 & 31.138 & 0.000 \\
\hline & IC4 & 0.785 & 0.035 & 22.377 & 0.000 \\
\hline & IC5 & 0.876 & 0.023 & 38.376 & 0.000 \\
\hline & IC6 & 0.838 & 0.031 & 26.621 & 0.000 \\
\hline & IC7 & 0.805 & 0.036 & 22.438 & 0.000 \\
\hline \multirow[t]{5}{*}{ TQM-LMC } & LMC1 & 0.833 & 0.048 & 17.415 & 0.000 \\
\hline & LMC2 & 0.845 & 0.045 & 18.667 & 0.000 \\
\hline & LMC3 & 0.729 & 0.075 & 9.719 & 0.000 \\
\hline & LMC4 & 0.860 & 0.028 & 30.853 & 0.000 \\
\hline & LMC5 & 0.874 & 0.029 & 30.472 & 0.000 \\
\hline \multirow[t]{5}{*}{ TQM-CF } & $\mathrm{FC1}$ & 0.836 & 0.043 & 19.610 & 0.000 \\
\hline & $\mathrm{FC2}$ & 0.888 & 0.026 & 34.398 & 0.000 \\
\hline & FC3 & 0.889 & 0.024 & 37.619 & 0.000 \\
\hline & FC4 & 0.876 & 0.026 & 33.813 & 0.000 \\
\hline & FC5 & 0.770 & 0.061 & 12.622 & 0.000 \\
\hline \multirow[t]{6}{*}{ TQM-PEM } & PEM1 & 0.776 & 0.048 & 16.007 & 0.000 \\
\hline & PEM2 & 0.902 & 0.018 & 48.850 & 0.000 \\
\hline & PEM3 & 0.873 & 0.027 & 32.599 & 0.000 \\
\hline & PEM4 & 0.836 & 0.034 & 24.449 & 0.000 \\
\hline & PEM5 & 0.854 & 0.033 & 26.169 & 0.000 \\
\hline & PEM6 & 0.829 & 0.032 & 25.801 & 0.000 \\
\hline \multirow[t]{5}{*}{ TQM-PRM } & PRM1 & 0.862 & 0.030 & 28.613 & 0.000 \\
\hline & PRM2 & 0.876 & 0.027 & 32.297 & 0.000 \\
\hline & PRM3 & 0.877 & 0.029 & 30.152 & 0.000 \\
\hline & PRM4 & 0.863 & 0.024 & 35.620 & 0.000 \\
\hline & PRM5 & 0.847 & 0.030 & 27.871 & 0.000 \\
\hline \multirow[t]{5}{*}{ TQM-QDR } & QDR1 & 0.769 & 0.054 & 14.229 & 0.000 \\
\hline & QDR2 & 0.854 & 0.028 & 30.611 & 0.000 \\
\hline & QDR3 & 0.894 & 0.017 & 51.832 & 0.000 \\
\hline & QDR4 & 0.856 & 0.032 & 26.818 & 0.000 \\
\hline & QDR5 & 0.902 & 0.021 & 42.850 & 0.000 \\
\hline
\end{tabular}


Table 3 T-value of the factor loadings (Continued)

\begin{tabular}{|c|c|c|c|c|c|}
\hline \multirow[t]{4}{*}{ TQM-SQM } & SQM1 & 0.773 & 0.048 & 15.948 & 0.000 \\
\hline & SQM2 & 0.774 & 0.062 & 12.419 & 0.000 \\
\hline & SQM3 & 0.631 & 0.101 & 6.248 & 0.000 \\
\hline & SQM4 & 0.862 & 0.026 & 32.709 & 0.000 \\
\hline
\end{tabular}

aTQM-LMC TQM leadership management commitment, TQM-CF TQM customer focus, TQM-PEM TQM people management, TQM-PRM TQM- processes management, TQM-QDR TQM quality data reporting, TQM-SQM TQM supplier quality management

and bootstrapping. A major emphasis in PLS-SEM analysis is on variance explained as well as establishing the significance of all path estimates. Specifically, the predictive power of the structural model is assessed by the $R^{2}$ values of the endogenous constructs (Chin 2010; Henseler et al. 2009), and then, the level and significance of the path coefficients (Hair et al. 2011). In other words, the quality of the structural model can be assessed by $R^{2}$ which indicates the variance in the endogenous variable that is explained by the exogenous variables. According to Cohen (1988), $R^{2}$ values for endogenous constructs are considered substantial if $\left(R^{2} \geq 0.26\right)$, moderate if $\left(R^{2} \geq 0.13\right)$ and weak if $\left(R^{2} \geq 0.02\right)$. Table 6 indicates the $R^{2}$ values of the endogenous constructs (i.e., innovation capability IC and innovation performance IP).

The obtained results in Table 6 clarify the ability of TQM practices to justify $64.9 \%$ of the variance in innovation capability IC, where both TQM practice and innovation capability account for $53.2 \%$ of variance in innovation performance. The following section evaluates the path coefficients of the targeted relationships. According to the reported results in Table 7, all the direct relationships postulated in this study were found to be positive and significant at 0.001 level of significance, except the hypothesis that proposed a positive influence of TQM practice on innovation performance was found to be insignificant, and therefore, $\mathrm{H} 1$ was rejected while $\mathrm{H} 2$ and $\mathrm{H} 3$ were supported by this study's results.

\section{The mediating effect of innovation capability}

The last part of the analysis in this study is to test the mediating role of innovation capability on the relationship between TQM practices and innovation performance (TQM - > IC - > IP) (Hypothesis 4). To do so, Baron and Kenny's (1986) criteria were applied. According to Baron and Kenny, three requirements need to be fulfilled in order to assume the possibilities of having a mediating variable in any interaction relationship; first, the relationship between the predictor TQM and the criterion

Table 4 Confirmatory Factor Analysis CFA

\begin{tabular}{lllll}
\hline \multicolumn{5}{l}{ Convergent validity } \\
\hline Construct & Items & Internal reliability Cronbacha & Composite reliability (CR) & Average Variance ExtractedAVE \\
TQM-LMC & 5-items & 0.886 & 0.917 & 0.689 \\
TQM-CF & 5-items & 0.906 & 0.930 & 0.728 \\
TQM-PEM & 6-items & 0.920 & 0.938 & 0.715 \\
TQM-PRM & 5-items & 0.916 & 0.937 & 0.749 \\
TQM-SQM & 4-items & 0.836 & 0.885 & 0.608 \\
TQM-QDR & 5-items & 0.908 & 0.932 & 0.733 \\
IC & 7-items & 0.916 & 0.933 & 0.665 \\
IP & 8-items & 0.925 & 0.939 & 0.658 \\
\hline
\end{tabular}


Table 5 Fornell-Larcker Criterion (Discriminant Validity) First Order Constructs

\begin{tabular}{lcllllllll}
\hline Constructs & Square root of AVE & IC & IP & CF & LMC & PEM & PRM & QDR & SQM \\
\hline IC & 0.816 & 1 & & & & & & \\
IP & 0.811 & 0.720 & 1 & & & & & \\
CF & 0.853 & 0.640 & 0.490 & 1 & & & & \\
LMC & 0.830 & 0.571 & 0.448 & 0.772 & 1 & & & \\
PEM & 0.846 & 0.707 & 0.611 & 0.692 & 0.582 & 1 & & \\
PRM & 0.865 & 0.669 & 0.577 & 0.781 & 0.668 & 0.808 & 1 & \\
QDR & 0.856 & 0.677 & 0.529 & 0.692 & 0.674 & 0.726 & 0.722 & 1 & \\
SQM & 0.780 & 0.681 & 0.528 & 0.650 & 0.641 & 0.671 & 0.728 & 0.709 & 1 \\
\hline
\end{tabular}

variable, innovation capability -path (a) needs to be established. Second, the relationship between the predictor innovation capability and the criterion variable innovation performance -path $(b)$ must be positive and significant. Finally, the direct relationship between TQM and innovation performance in the absence of the innovation capability -path (c) has to be significant and positive.

As Fig. 2 demonstrates, the result of PLS-SEM points to a significant impact of TQM on innovation capability $(\beta=0.341, \mathrm{t}=3.987, p<0.001)$ with high beta value and the $t>1.96(\mathrm{H} 3)$, and thus, the first condition is fulfilled. With regards to the second condition, the result also confirms the significant impact of innovation capability on innovation performance $(\beta=0.564, \mathrm{t}=5.694, p<0.001)$, where the beta value is considered high and $t>1.96(\mathrm{H} 2)$. The third condition, which refers to the direct relationship between TQM and innovation performance, in the absence of innovation capability, must be significant. The outcome of PLS-SEM indicates that there is a positive and statistically significant relationship $(\beta=0.619, \mathrm{t}=11.280, p<0.001)$, with high beta value, and, value of $\mathrm{t}>1.96$. Comparing the path value to TQM and innovation performance, it is found that this value is reduced in the presence of the mediating variable (innovation capability) $\left(c^{\prime}\right)$, and, more importantly, the path value was not significant $(\beta=0.119, \mathrm{t}=0.989, p<$ 0.161 ) and it had $t$ value of less than $<1.96(\mathrm{H} 1)$. Therefore, a full mediation role of innovation capability is revealed and confirmed in the relationship between TQM and innovation performance at $\mathrm{t}$ value $>1.96$ and $p<0.005$. Furthermore, the Variance Accounted For (VAF) value shows that $62 \%$ of the total effect of TQM on innovation performance comes through in direct effect of innovation capability. This result indicates that TQM practices have a critical indirect impact on innovation performance, and therefore, applying TQM practices will help to provide the infrastructure that will pave the way to enhance innovation performance.

$$
V A F=\frac{0.341 \times 0.564}{0.193+0.119}=0.62
$$

Table 6 R-square of endogenous constructs

\begin{tabular}{lcl}
\hline Construct & R-square & Result \\
\hline IC & 0.649 & Substantial \\
IP & 0.532 & Substantial \\
\hline
\end{tabular}


Table 7 Direct path coefficients of the inner model (Hypotheses)

\begin{tabular}{lcclll}
\hline Hypothesized Path & Path Coefficient $(\beta)$ & T-value & P-value & Result & Hypothesis \\
\hline TQM - > IP & 0.116 & 0.916 & 0.180 & Not supported & $\mathrm{H} 1$ \\
IC - > IP & 0.555 & 5.161 & $0.000^{* * *}$ & Supported & $\mathrm{H} 2$ \\
TQM - > IC & 0.292 & 3.721 & $0.000^{* * *}$ & Supported & $\mathrm{H} 3$ \\
\hline
\end{tabular}

*** Significant at level $0.001(* * *<0.001)$

\section{Discussion and conclusion}

This study targeted to reduce the existing gap in the literature as to the relationship TQM practices and innovation performance. To do so, this paper extended the relationship between TQM practice and innovation performance to examine the influence of the mediating role of innovation capability in this relationship. This study established innovation capability as one of the critical requirements of innovation performance. This result is in line with the results of other previous studies like Yang et al. (2009) and Yusr, Mokhtar and Othman (2013). This finding, moreover, suggests that the companies, which plan to be creative companies and build competitive advantage through innovation, need to pay more attention to and exert more effort into building their innovation capabilities.

On the other hand, the outcome of this research found that TQM practices have a superior role in enhancing innovation capability, and the obtained result of R-square proved that $\left(R^{2}=0.65\right)$. Therefore, this study introduces TQM practices as the foundation of building innovation capability in the manufacturing companies. This statement is supported by RBV theory, where the theory emphasizes on the role of the valuable resources that a company may own in building certain distinguished capabilities. This conclusion, furthermore, is supported by Perdomo-Ortiz et al. (2006), where they examined the role of TQM practices as an antecedent of innovation capability in the industrial sector in Spain. The authors found a strong positive link between TQM practices and innovation capability.

Additionally, our findings support the conclusions of Singh and Smith (2004), Prajogo and Sohal (2006), and Abrunhosa and Sá (2008) that TQM practices do not have a direct impact on innovation performance, rather this effect of TQM practice on innovation performance can be captured indirectly. This result, furthermore, is supported by the result of the full mediating role of innovation capability on the relationship between TQM practices and innovation performance. Accordingly, although the

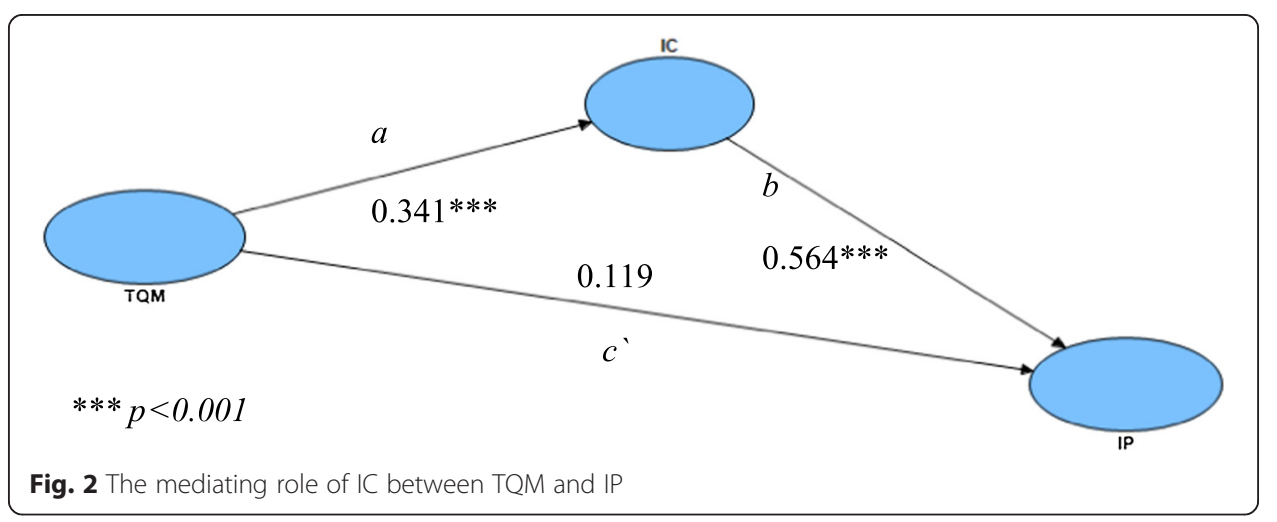


direct influence of TQM practices on innovation performance was not supported by this study, applying TQM practices are still needed to enhance the innovation performance by contributing to building the necessary capabilities that reinforce innovation performance. Therefore, this study emphasizes the manufacturing companies need to support the successful application of TQM practices. Future studies can further examine the effect of each TQM practice on enhancing innovation capability, the knowledge that can help to provide a clear picture to determine the most influential practices of TQM on innovation capability. Conducting case studies could also help to get a deep insight about the mechanism through which TQM practices could enhance innovation capability and as a result, improve innovation performance.

Received: 7 November 2015 Accepted: 26 January 2016

Published online: 22 February 2016

\section{References}

10th Malaysia Plan. (2010). Economic Planning unit. Retrieved from www.epu.gov.my/en/tenth-malaysia-plan-10thmp. Abrunhosa, A., \& Sá, P. M. E. (2008). Are TQM principles supporting innovation in the Portuguese footwear industry? Technovation, 28(4), 208-221. doi:10.1016/j.technovation.2007.08.001.

Ahire, S. L., \& O'Shaughnessy, K. C. (1998). The role of top management commitment in quality management: an empirical analysis of the auto parts industry. International Journal of Quality Science, 3(1), 5-37.

Ahmed, A. Y. M. (2011). Internet technology factors, quality information delivery and supply chain information performance in Malaysian manufacturing companies. Unpublished PhD thesis. University Utara Malaysia.

Amit, R., \& Schoemaker, P. J. H. (1993). Strategic assets and organizational rent. Strategic Management Journal, 14(1), 33-46.

Barney, J. (1991). Firm resources and sustained competitive advantage. Journal of Management, 17(1), 99.

Baron, R. M., \& Kenny, D. a. (1986). The moderator-mediator variable distinction in social psychological research: conceptual, strategic, and statistical considerations. Journal of Personality and Social Psychology, 51(6), 1173-1182.

Black, S. a., \& Porter, L. J. (1996). Identification of the Critical Factors of TQM. Decision Sciences, 27(1), 1-21.

Brah, S. a., Tee, S. S. L., \& Rao, B. M. (2002). Relationship between TQM and performance of Singapore companies. International Journal of Quality \& Reliability Management, 19(4), 356-379. doi:10.1108/02656710210421553.

Byrne, B. M. (2010). Structural equation modeling with AMOS: basic concepts, applications, and programming (2nd ed.). New York, London: Taylor \& Francis Group.

Calantone, R. J., Cavusgil, S. T., \& Zhao, Y. (2002). Learning orientation, firm innovation capability, and firm performance. Industrial Marketing Management, 31, 515-524. doi:10.1016/S0019-8501(01)00203-6.

Cavusgil, S. T., Calantone, R. J., \& Zhao, Y. (2003). Tacit knowledge transfer and firm innovation capability. Journal of Business \& Industrial Marketing, 18(1), 6-21. doi:10.1108/08858620310458615.

Chin, W. W. (2010). How to Write Up and Report PLS Analyses. In V. E. Vinzi, W. W. Chin, J. Henseler \& H. Wang ( Eds.), Handbook of Partial Least Squares Concepts, Methods and Applications, Berlin: Springer-Verlag, 650-690.

Choi, T. Y., \& Liker, J. K. (1995). Bringing Japanese continuous improvement approaches to U.S. manufacturing: The roles of process orientation and communications. Decision Sciences, 26(5), 589-620.

Cobbenhagen, J. (2000). Successful innovation towards a new theory for the management of small and medium-sized enterprises. Cheltenham: Edward Elgar.

Cohen, J. (1988). Statistical power analysis for the behavioral sciences (2nd ed.). Hillsdale, Lawrence Erlbaum Associates, NJ.

Cole, R. E., \& Matsumiya, T. (2008). When the pursuit of quality risks innovation. The TQM Journal, 20(2), 130-142. doi:10. $1108 / 17542730810857363$.

Cooper, J. (1998). A multidimensional approach to the adoption of innovation. Management Decision, 36(8), 493-502.

Fornell, C., \& Larcker, D. F. (1981). Evaluating structural equation models with unobservable variables and measurement Error. Journal of Marketing Research, XVIII(Feb), 39.

Hair, J. F., Black, W. C., Babin, B. J., Anderson, R. E. (2010). Multivariate data analysis: a global perspective. (7th Ed.). Upper Saddle River, N.J.: Pearson Education.

Hair, J. F., Ringle, C. M., \& Sarstedt, M. (2011). PLS-SEM: Indeed a Silver Bullet. Journal of Marketing Theory and Practice, 19(2), 139-152.

Han, J. K., Kim, N., \& Srivastava, R. K. (1998). Market orientation and organizational performance: is innovation a missing link? Journal of Marketing, 62(October), 30-45.

Henseler, J., Ringle, C. M., \& Sinkovics, R. R. (2009). The use of partial least squares path modeling in international marketing. Advances in International Marketing, 20, 277-319.

Herbig, P. (1995). Innovation Japanese style a cultural and historical perspective. Westport: Quorum.

Hulland, J. (1999). Use of Partial Least Squares (PLS) in strategic management research: a review of four recent studies. Strategic Management Journal, 20, 195-204.

Hurley, R. F., \& Hult, G. T. M. (1998). Innovation, market orientation, and organizational learning: an integration and empiricai examination. Journal of Marketing, 62(July), 42-54.

Kanji, G. K. (1996). Can total quality management help innovation? Total Quality Management, 7(1), 3-10. doi:10.1080/09544129650035007.

Kaynak, H. (2003). The relationship between total quality management practices and their effects on firm performance. Journal of Operations Management, 21(4), 405-435.

Kordupleski, R. E., Rust, R. T., \& Zahorik, A. J. (1993). Why improving quality doesn't improve quality (or whatever happened to marketing?). California Management Review, 35(3), 82-95. doi:10.2307/41166745. 
Lall, S. (1992). Technological capabilities and industrialization. World Development, 20(2), 165-186.

Lau, A. K. W., Yam, R. C. M., \& Tang, E. P. Y. (2010). The impact of technological innovation capabilities on innovation performance: An empirical study in Hong Kong. Journal of Science and Technology Policy in China, 1(2), 163-186. doi:10.1108/17585521011059893.

Lawson, B., \& Samson, D. (2001). Developing innovation capability in organisations: a dynamic capabilities approach. International Journal of Innovation Management, 05(03), 377-400.

Lockamy, A. (1998). Quality-focused performance measurement systems: a normative model. International Journal of Operations \& Production Management, 18(8), 740-766.

López-Mielgo, N., Montes-Peón, J. M., \& Vázquez-Ordás, C. J. (2009). Are quality and innovation management conflicting activities? Technovation, 29(8), 537-545. doi:10.1016/j.technovation.2009.02.005.

Martínez-Costa, M., \& Jiménez-Jiménez, D. (2008). Are companies that implement TQM better learning organisations? An empirical study. Total Quality Management and Business Excellence, 19(11), 1101-1115. doi:10.1080/14783360802323446.

Ministry of Finance (2011). Economic Performance and Prospects 2010-2011. Retrieved from http://www.treasury.gov.my/ pdf/economy/er/1011/chap3.pdf

Ministry of Finance (2012). Economic Performance and Prospects. Retrieved from http://www.treasury.gov.my/pdf/ ekonomi/le/1213/chap3.pdf

National Survey of innovation, 2005-2008 (2011). Malaysian Science and technology Information Center. Retrieved from www.mastic.gov.my/en/web/guest/national-innovation-survey.

Pavlou, P. A., \& El Sawy, O. A. (2011). Understanding the elusive black box of dynamic capabilities. Decision Sciences, 42(1), 239-273. doi:10.1111/j.1540-5915.2010.00287.x.

Pekovic, S., \& Galia, F. (2009). From quality to innovation: evidence from two French employer surveys. Technovation, 29, 829-842.

Perdomo-Ortiz, J., González-Benito, J., \& Galende, J. (2006). Total quality management as a forerunner of business innovation capability. Technovation, 26, 1170-1185. doi:10.1016/j.technovation.2005.09.008.

Perdomo-Ortiz, J., González-Benito, J., \& Galende, J. (2009). The intervening effect of business innovation capability on the relationship between total quality management and technological innovation. International Journal of Production Research, 47(18), 5087-5107.

Pinho, J. C. (2008). TQM and performance in small medium enterprises The mediating effect of customer orientation and innovation. International Journal of Quality \& Reliability Management, 25(3), 256-275.

Porter, E. M. (1980). Competitive strategy: techniques for analyzing industries and competitors. New York: A Division of Macmillan Publishing Co., Inc.

Prajogo, D. I., \& Hong, S. W. (2008). The effect of TQM on performance in R\&D environments: A perspective from South Korean firms. Technovation, 28(12), 855-863. doi:10.1016/j.technovation.2008.06.001.

Prajogo, D. I., \& Sohal, A. S. (2001). TQM and innovation: a literature review and research framework (Vol. 21, pp. 539-558).

Prajogo, D. I., \& Sohal, A. S. (2003). The relationship between TQM practices, quality performance, and innovation performance: an empirical examination. International Journal of Quality \& Reliability Management, 20(8), 901-918.

Prajogo, D. I. \& Sohal, A. S. (2004). Transitioning from total quality management to total innovation management: an Australian case. International Journal of Quality \& Reliability Management, 21(8), 861-875. doi:10.1108/02656710410551746.

Prajogo, D. I., \& Sohal, A. S. (2006). The relationship between organization strategy, total quality management (TQM), and organization performance--the mediating role of TQM. European Journal of Operational Research, 168(1), 35-50. doi:10.1016/j.ejor.2004.03.033.

Prajogo, D. I., Power, D. J., \& Sohal, A. S. (2004). The role of trading partner relationships in determining innovation performance: an empirical examination. European Journal of Innovation Management, 7(3), 178-186.

Roffe, I. (1999). Innovation and creativity in organisations: a review of the implications for training and development. Journal of European Industrial Training, 23(4), 224-241.

Sadikoglu, E., \& Zehir, C. (2010). Investigating the effects of innovation and employee performance on the relationship between total quality management practices and firm performance: an empirical study of Turkish firms. International Journal of Production Economics, 127, 13-26. doi:10.1016/j.jpe.2010.02.013.

Singh, P. J., \& Smith, A. J. R. (2004). Relationship between TQM and innovation: an empirical study. Journal of Manufacturing Technology Management, 15(5), 394-401.

Tang, H. K. (1998). An integrative model of innovation in organizations. Technovation, 18(5), 297-309.

Teece, D. J., Pisano, G., \& Shuen, A. M. Y. (1997). Dynamic capabilities and strategic management. Strategic Management Journal, 18(7), 509-533.

Tuah, H., Nadaraja, D., \& Jaafar, Z. (2009). Benchmarking Malaysia's innovation capacity. Kuala Lumpur: 8th Globelics International Conference.

Tuominen, M., \& Hyvönen, S. (2004). Organizational innovation capability: a driver for competitive superiority in marketing channel. The International Review of Retail, Distribution and Consumer Research, 14(3), 277-293.

Wernerfelt, B. (1984). A resource-based view of the firm. Strategic Management Journal, 5, 171-180. doi:10.1002/smj.4250050207.

Wind, J., \& Mahajan, V. (1997). Issues and opportunities in new product development: an introduction to the special issue. Journal of Marketing Research, XXXIV(February), 1-12.

Yam, R. C. M., Guan, J. C., Pun, K. F., \& Tang, E. P. Y. (2004). An audit of technological innovation capabilities in chinese firms: some empirical findings in Beijing, China. Research Policy, 33(8), 1123-1140.

Yam, R. C. M., Lo, W., Tang, E. P. Y., \& Lau, A. K. W. (2011). Analysis of sources of innovation, technological innovation capabilities, and performance: an empirical study of Hong Kong manufacturing industries. Research Policy, 40(3), 391-402. doi:10.1016/.j.respol.2010.10.013.

Yang, C.-C., Marlow, P. B., \& Lu, C.-S. (2009). Assessing resources, logistics service capabilities, innovation capabilities and the performance of container shipping services in Taiwan. International Journal of Production Economics, 122, 4-20. doi:10.1016/j.jpe.2009.03.016.

Yusr, M. M., Mokhtar, S. S. M., \& Othman, A. R. (2013). Examining the relationship among TQM, organizational learning and innovation performance. World Applied Sciences Journal, 23(special Issue), 22-26.

Zheng, S., Zhang, W., \& Du, J. (2011). Knowledge-based dynamic capabilities and innovation in networked environments. Journal of Knowledge Management, 15(6), 1035-1051. doi:10.1108/13673271111179352. 